\title{
Building user commitment to implementing a knowledge management strategy
}

\author{
Duncan Shaw*, John S. Edwards
}

\begin{abstract}
In the IS literature, commitment is typically considered to involve organizational or managerial support for a system and not that of its users. This paper however reports on a field study involving 16 organizations that attempted to build user involvement in developing a knowledge management strategy by having them design it. Twenty-two IT-supported group workshops (involving 183 users) were run to develop action plans for better knowledge management that users would like to see implemented. Each workshop adopted the same problem structuring technique to assist group members develop a politically feasible action plan to which they were psychologically and emotionally dedicated. In addition to reviewing the problem structuring method, this paper provides qualitative insight into the factors a knowledge management strategy should have to encourage user commitment. \# 2004 Elsevier B.V. All rights reserved.
\end{abstract}

Keywords: User commitment; Communities of implementation; Group workshops; Knowledge management strategy; Problem structuring methods

\section{Introduction}

The social side of knowledge management (KM) has developed methods that encourage good practice; e.g. communities of practice, social/knowledge networks [27] and small group workshops [48]. However, the focus is seldom on designing a KM strategy; more often they concentrate on the operational level; the sharing, retention, utilisation, and acquisition of

knowledge among individuals within, or across, organizations $[19,28]$.

Here, we take a perspective of commitment-to taking-action, that is, both the individual and collective, psychological and emotional desire of a group of people to take an action in order to achieve agreed and shared objectives [18]. We do not follow either a commitment-to-strategy or a commitment-to change perspective [38] because these imply that others have generated the plan, which is not the case here.

Commitment has been discussed in the IS/IT literature but has almost exclusively focused on the dedication of the individual to the organization rather than to the system or plan being implemented. Even in the rare cases where the focus has been on the user, it has not been on the factors that build their commitment-typically it has been on understanding the organizational factors that encourage user support, or influence executive peer engagement.

There is an extensive body of work on acceptance of IS, much of it deriving from the Theory of Reasoned Action [21]. This includes research using the
Technology Acceptance Model developed by Davis [12] and its extensions (e.g. Legris et al. [35]). Much of this literature examines concepts such as behavioral intention, user involvement [31] and intrinsic motivation [59]. However, the difference between commitments, as used in this paper, and this work is our inclusion of participation in the high-level design of the system or action plan, at the earliest possible stage in its development. This has, of course, been known in some works as participative design [3].

For KM, developing and building commitment has largely been influenced by the literature of change management, intellectual capital, DSS, project management, and strategy. However, these tend to stop short of exploring the factors/characteristics needed to warrant the users agreeing to enforce it.

Here, we worked mostly with the people who would be the users; their task was to design a KM action plan, which they individually and collectively agreed to execute. By design, the majority of the users were also managers (junior, operational, middle, and executive). They were targeted specifically to aid implementation, because this " is made easier when middle management are involved in developing the business case" and "senior management is motivated by a business case 
that links any investment in a $\mathrm{KM}$ initiative to the strategic returns"' [37]. By having participants from a range of roles in the management hierarchy, we tried to identify and help the group overcome any potential mismatch between strategic and operational perspectives. Therefore, this should have resolved any differences between top-down and bottom-up views. Thus, we aimed to strengthen support for roll-out across the organization.

We used a methodology for group working called Journey Making [JOint Understanding, Reflection and NEgotiation of strategY (in our case, KM strategy)] [17]. It was developed to assist groups build action plans and is an IT-supported problem structuring method, which helps groups to collectively understand their problem through explicit modelling of the diverse perspectives of the group members. Such techniques have often been termed Group Decision Support Systems [33,56]. Journey Making was used to assist 22 groups from 16 organizations to build action plans for better $\mathrm{KM}$ in their organization during day-long workshops. These therefore, enabled 183 managers to share (and researchers to capture) their views on the design of the plan.

\section{Commitment and knowledge management}

Despite several decades of observations from Drucker (e.g. [16]) on the criticality of the commitment of knowledge workers to KM systems, much of the literature views involvement solely in terms of what the organization and the managers do. The organization shows its support for a system in the form of resources; managers demonstrate this in the form of leadership. For example, Newman and Sabherwal [40] discussed commitment to IS development by considering a longitudinal case study over 17 years. Their effort was solely in terms of managerial involvement. Even when "social determinants" of involvement were discussed, it was still the managerial peer group rather than the user peer group.

This approach can also be seen in the KM literature. For example, Inkpen [30] identifies six success factors, one of which is the importance of leadership involvement, while Desouza [14] considered leadership in informal aspects of KM, such as the use of game rooms. However, support for any action plan was not considered more widely.
Alavi and Leidner [2] developed an extensive research agenda for $\mathrm{KM}$ systems. It is noticeable, however, that they gave little consideration to willingness to use such a system, although they did mention the "need for organizational members to remain attuned to contextual factors and explicitly consider the circumstances of the current environment." Non-supporting employees are simply not likely to do this. Grover and Davenport's [26] discussion of a KM research agenda also mentioned individual motivation only in passing. Choi and Lee [8] explored four different styles of KM for an organization but again commitment and motivation were not discussed in any detail.

By contrast, Ulrich [57], who looked at this from an intellectual capital perspective, took a very different standpoint. He saw individual belief and motivation as one of the crucial elements of intellectual capital. He identified no fewer than 10 factors as important in securing this; remuneration is only one. He described this factor (termed Shared Gains) as " when the line of sight between work and reward is clear.' Other factors included strategy or vision, collaboration and teamwork, communication, and concern for people. Individual belief was studied by McKenzie et al. [37] who noted (in addition to the importance of user and senior/middle management involvement) that individual support for $\mathrm{KM}$ initiatives is linked to support from senior management, that a dedicated champion gives credibility to the initiative and that recognition of the project team might lead to further action.

Malhotra and Galletta [36] offered a theoretical basis for user motivation to the adoption of $\mathrm{KM}$ systems. Their study focused on implemented systems; consequently, the relationship between involvement during systems design and commitment to its use was outside their scope.

Enns et al.'s [20] research on executive peer groups suggested that when building an executive's commitment to IS proposals, consultation was not always the best approach. This suggested that consultation was not enough; therefore, we suggested that individual commitment could be better built by getting these people to help design the proposal/system.

This 'individual commitment' view can also be found in the literature for DSS. For example, Sprague [54] discussed systems to improve the performance of knowledge workers. He proposed that a DSS should be 
easy to use and that it should be user driven. Sprague and Carlson [55] pointed out that "the cardinal rule in DSS is to be driven by user needs"' and also that "fundamental requirements for developing any computer-based system are user involvement and management involvement."' Garvey and Williamson [24] went even further by suggesting that "successful change is sensitively negotiated, owned by those who participate in it and is based on new learning to enable people to think in new ways.",

Huber [29] addressed motivational issues, pointing out that the problems of securing adoption and ongoing use of systems bear similarities to the problems of persuading people to use IT systems at all in the early days of computing. These problems were not "solved"' by financial incentives or organizational directives [42]. Knowledge transfer depends on the absorptive capacity of the receiving unit, but Cohen and Levinthal [9] in their paper on absorptive capacity do not discuss willingness, motivation, or commitment. Huber concluded that there is an "important need for research to examine the additive, conflicting, and interactive effects of extrinsic motivators, intrinsic motivations, and social-psychological forces in the context of

\subsection{Relevant features of a PSM}

Shaw et al. [51] identify six features of a PSM. These are summarised in Table 1. Each contributes to building the commitment of the participants to the knowledge transfer."’

\section{Problem structuring for building group commitment}

Problem structuring methods (PSM) [47] are ways of facilitating structured thinking about complex problems that can be used with individuals or groups. They may be used to facilitate a group in developing a clear programme of actions to achieve goals to which they are collectively committed.

A messy problem is characterised by "extreme ambiguity" and "a whole range of possible definitions and descriptions of what is going on" [44]. In such problems, there is a diversity of issues to be faced and tackled, and the inter-relationships between the issues are complex but critical to the interpretation of the problem and whether a solution even exists. These types of problems have also been described as "wicked"' [46].

PSM include: Soft Systems Methodology (SSM) [7]; Strategic Choice [23]; Dialog Mapping [10]; and Journey Making.

resultant action plan for addressing the problem. Many of these features also distinguish PSM from other group methods (in particular the role of the model and social aspects). 
Table 1

Six features of PSMs and how Journey Making addresses these

\begin{tabular}{|c|c|}
\hline Features of PSMs & Characteristics of Journey Making addressing this \\
\hline $\begin{array}{l}\text { 1. Building a group into a supportive unit to collectively } \\
\text { tackle a messy problem. Accountability to the group } \\
\text { reinforces commitment and the motivation to act [25]. }\end{array}$ & $\begin{array}{l}\text { Everyone together in the same room, jointly understanding } \\
\text { the complexity and exploring ways of jointly managing this. }\end{array}$ \\
\hline $\begin{array}{l}\text { 2. An emphasis on explicit model building to manage the } \\
\text { complexity of knowledge shared, and to act as a device } \\
\text { through which the participants can negotiate the legitimacy } \\
\text { of competing perspectives. }\end{array}$ & $\begin{array}{l}\text { Causal mapping engages the group members in modelling } \\
\text { the breadth and depth of issues to enable more to be } \\
\text { uncovered and analysed. }\end{array}$ \\
\hline $\begin{array}{l}\text { 3. Providing a transparent, logical, procedurally just process [34] } \\
\text { whereby psychological belief can be built to an outcome } \\
\text { which the group agree will achieve the goals i.e. actions } \\
\text { are substantively rational [53]. }\end{array}$ & $\begin{array}{l}\text { With facilitator support: the participants design the workshop } \\
\text { enabling their critical issues to be addressed; real progress } \\
\text { is made on building an action plan [1]; the model provides } \\
\text { an audit trail of agreeing actions, aiding transparency; } \\
\text { participants have effective opportunities to influence } \\
\text { the outcome. }\end{array}$ \\
\hline $\begin{array}{l}\text { 4. The prioritisation of social negotiation supports reaching } \\
\text { agreement on contentious issues and encourages engaging } \\
\text { emotionally in their implementation. }\end{array}$ & $\begin{array}{l}\text { In Journey Making, NEgotiation is prioritised through } \\
\text { structured, facilitated discussion by the right people who } \\
\text { are together in the room. Electronic support potentially } \\
\text { reduces some of the destructive properties of negotiation } \\
\text { [32]. Agreement/conflict is recorded in the model. }\end{array}$ \\
\hline $\begin{array}{l}\text { 5. Through negotiation and debate the participants reconcile } \\
\text { competing perspectives and agree a shared action plan. } \\
\text { This is not usually zero-sum negotiation and so satisficing } \\
\text { is not required [60]. Selection between actions ensures only } \\
\text { the most valid actions are carried out. }\end{array}$ & $\begin{array}{l}\text { To ensure rigorous consideration of all issues, the facilitator } \\
\text { welcomes constructive tension between views and assists in } \\
\text { the identification of conflict (and its exploration and } \\
\text { resolution where appropriate). }\end{array}$ \\
\hline $\begin{array}{l}\text { 6. The role of the facilitator in the whole process including: } \\
\text { content management of the issues/discussion; process } \\
\text { management of the group dynamics; making progress } \\
\text { through the problem; encouraging commitment through } \\
\text { supporting Features } 1-5 \text {. }\end{array}$ & $\begin{array}{l}\text { The facilitator will support: content management through } \\
\text { mapping discussion using the mapping software; process } \\
\text { management through group explorer software and facilitation } \\
\text { techniques; the group using the Journey Making methodology } \\
\text { based on Features 1-5. }\end{array}$ \\
\hline
\end{tabular}

Of course, "involvement alone does not create commitment" [22] and so a PSM goes further than involvement. Emotional engagement with actions is built through prioritising social negotiation to agree on contentious issues [43], and learn about other perspectives [58]. Rarely will consensus be reached which satisfies all the competing perspectives, but facilitators will aim, at the very least, for actions to retain enough of the issues important to each participant.

\subsection{The Journey Making approach}

Although PSM workshops are fundamentally a psychological and social process, IT can help [6]. However, while the facilitator of a Dialog Mapping and Strategic Choice workshop can only enter content into the electronic model on behalf of the participants, the facilitator of a Journey Making workshop has a full GDSS allowing participants to enter content directly into the model through their own networked computer.

Like most modern GDSS, Journey Making, using Group Explorer software, involves participants typing their opinions on the situation/problem into their computer. The facilitator advises participants that each concept entered into the computer should be 410 words in length to ensure that they are meaningful to other people. These form the basis of the model. In Journey Making the model is a causal map (publicly projected to the group) that contains the perspectives of each participant and the inter-relationships between all perspectives, see [50]. The inter-relationships are represented by links/arrows between the concepts entered by the participants or by the facilitator. For example, "conduct exit questionnaires" and "encourage work-in-progress presentations" are ways of "collect [ing] project-specific knowledge 
before people leave the company."' All entries to the model are logged in a database.

Some advantages of this approach are specific examples of the group support system (GSS) experimental literature: anonymously typing concepts into the computers to avoid being apprehensive about sharing their contributions [41] and to gain confidence when sharing controversial views [11]; simultaneously typing/sharing concepts to avoid waiting for others

[15] and freeing more time to discuss the concepts [13]; sharing ideas before discussing them rather than focussing too early on a definition/solutions [49].

In Journey Making these advantages help the facilitator to provide a process where all participants can share their perspectives without hindrance, concern, or influence. The technology helps extensively in managing and recording the mass of detail.

Table 2

Summary details of the organizations

\begin{tabular}{|c|c|c|}
\hline Organization & Brief description & No. of participants \\
\hline Ambulance (three workshops) & $\begin{array}{l}\text { Non-profit provider of ambulance care, } \\
172 \text { ambulance stations, } 3500 \text { employees. }\end{array}$ & $6,7,11$ \\
\hline B2B & $\begin{array}{l}\text { Business-to-business services, } \\
12,000 \text { employees, turnover } £ 200 \mathrm{M} \text {, listed PLC. }\end{array}$ & 8 \\
\hline Consult A & $\begin{array}{l}\text { International technicalengineering consultancy, } \\
\text { division of FTSE100 PLC. }\end{array}$ & 7 \\
\hline Consult B & $\begin{array}{l}\text { International energy consultancy, division of a } \\
\text { privately owned Dutch company. }\end{array}$ & 10 \\
\hline ConsumProt (two workshops) & $\begin{array}{l}\text { Not-for-profit membership owned non-statutory } \\
\text { consumer protection body. }\end{array}$ & $8,8,7$ \\
\hline DesignInst & $\begin{array}{l}\text { Design/installation of high technology equipment, } \\
\text { subsidiary of overseas listed company. }\end{array}$ & 6 \\
\hline HighTechManuf & $\begin{array}{l}\text { Manufacturing high technology, } £ 100 \mathrm{M} \text { turnover } \\
\text { and } 800 \text { employees, privately owned. }\end{array}$ & 7 \\
\hline Hospital A & Non-profit local hospital, 1000 beds, 4000 employees. & 7 \\
\hline Hospital B & Non-profit local hospital, 350 beds, 1100 staff. & 11 \\
\hline Housing & $\begin{array}{l}\text { Non-profit registered social landlord, } \\
500 \text { employees managing } 5500 \text { homes. }\end{array}$ & 5 \\
\hline ManufIndProd & Manufacturing industrial products, privately owned & 10 \\
\hline Police (three workshops) & Public sector/police force with 3700 staff and $£ 140 \mathrm{M}$ budget. & $9,12,5$ \\
\hline Property & $\begin{array}{l}\text { Office property construction, leasing and management, } \\
6 \mathrm{M} \text { (net) square feet of office space, } \\
8.1 \mathrm{M} \text { under construction, listed PLC in the FTSE } 100 .\end{array}$ & 11 \\
\hline Restaurants & $\begin{array}{l}\text { Retail/service business with about } 12 \text { major brand names, } \\
\text { division of FTSE100 PLC. }\end{array}$ & 8 \\
\hline Retail & $\begin{array}{l}\text { One of the United Kingdom's largest non-food retail chains, } \\
\text { turnover } £ 2.8 \mathrm{BN} \text {, division of FTSE100 PLC. }\end{array}$ & 11 \\
\hline $\mathrm{R} \& \mathrm{D}$ & $\begin{array}{l}\text { Non-profit distributing membership-owned research and } \\
\text { development, } 550 \text { employees. }\end{array}$ & 9 \\
\hline Total & & 183 \\
\hline
\end{tabular}

M, million; BN, billion; PLC, public limited company; FTSE100 consists of the 100 largest companies listed on the UK stock exchange.
4. Methodology

4.1. The organizations and participants

Twenty-two groups from 16 organizations in the United Kingdom were studied-summary details of each organization and workshop are given in Table 2 . Each group used the Journey Making workshop methodology. Each workshop was one day-long (apart from the third Police workshop, which lasted only a half day). The organizations were self selecting in that they responded to an invitation to participate.

Participants were invited by the client-who was told that at least one participant should be on the main board or have the authority to support action with resources. This attempted to ensure that the actions were either in alignment with the wider organizational imperatives or had the approval of someone who could sanction and fund their implementation. The other participants were supposed to hold some responsibility for or interest in $\mathrm{KM}$ and represent a broad cross-section of the organization - the potential users of the systems. 


\subsection{Capturing insight}

A field study approach was used to determine the groups' action plan. One facilitator was available to provide content management and process support. He did not add to the substance of what was discussed. At each workshop there was also at least one of two researchers who were tasked with recording observations. They wrote notes on the process, group dynamics, and content of the discussion.

Participants were asked to provide quantitative and qualitative feedback through exit questionnaires: 149 were gathered from 183 participants. Quantitative results from questions posed on a Likert scale are shown in Table 3.

Table 3 Quantitative responses from the exit questionnaires

\begin{tabular}{|c|c|c|}
\hline Question & Mean & S.D. \\
\hline $\begin{array}{l}\text { I think that knowledge management } \\
\text { is an important issue in our }\end{array}$ & 1.42 & 0.63 \\
\hline \multicolumn{3}{|l|}{ organization. } \\
\hline $\begin{array}{l}\text { I thought that the process was useful } \\
\text { in helping us to explore knowledge }\end{array}$ & 1.58 & 0.64 \\
\hline \multicolumn{3}{|l|}{ management. } \\
\hline $\begin{array}{l}\text { I have learned a lot during this } \\
\text { workshop. }\end{array}$ & 1.98 & 0.78 \\
\hline $\begin{array}{l}\text { I think that the outcome was generated } \\
\text { in an appropriate way. }\end{array}$ & 1.76 & 0.61 \\
\hline $\begin{array}{l}\text { I feel that I have had an impact on the } \\
\text { outcome. }\end{array}$ & 1.86 & 0.78 \\
\hline I think that the outcome of the workshop & 1.95 & 0.75 \\
\hline \multicolumn{3}{|l|}{ was the right list of things that we } \\
\hline \multicolumn{3}{|l|}{ need to do. } \\
\hline I hope that these outcomes will & 1.49 & 0.69 \\
\hline \multicolumn{3}{|l|}{ influence what our organization } \\
\hline \multicolumn{3}{|l|}{ does on knowledge management. } \\
\hline $\begin{array}{l}\text { I expect that these outcomes will } \\
\text { influence what our organization }\end{array}$ & 2.19 & 0.83 \\
\hline
\end{tabular}

$\mathrm{N}=149:$, strongly agree; 5, strongly disagree.

Participants were also asked to explain their rating/ response to questions. From these qualitative responses and the invitation to make any additional comments at the end of the questionnaire, we amassed many comments. These showed why participants had a sense of loyalty to the actions. The factors in the action plan were discovered through qualitative content analysis [5] of these comments.

\section{Factors to build commitment}

The qualitative comments collected from the questionnaires included issues that participants felt were important when developing an action plan. Comments were made on: (1) the characteristics of the actions; (2) the process of the event; (3) the actions influencing the organization.

To provide context to each consideration, we provide examples of participants' commentshowever, due to space restrictions only two comments under each heading were selected.

Participants perceived that their action plan should be:

- Achievable, including specific actions, which can be implemented in the desired time-frame: " "There is so much that we need to do to improve our KM ...this provides ... an achievable list of actions.”' [R\&D]; “'The outcome of the workshop identified key action points, including a specific action plan for research."' [Housing].

- $\quad$ Focussed on the relevant issues: "As the questions of the session were defined by (us) it was our issues that were worked not 'blue sky.' Much more realistic." [HighTechManuf]; " "The approach followed allowed ...(the) discussion of many relevant ideas and thoughts."' [Consult A].

- $\quad$ Thorough: "Much more interesting and wide reaching, all embracing, than I expected." [Police]; “'(KM is) an impossibly large subject. The workshop illustrated the breadth of what needs to be done while finishing with some achievable actions.', [R\&D].

- Filled with appropriate actions, not necessarily original ones: "'Some of the ideas ....are already in the provisional plans ... so this helped consolidate this direction." [B2B]; “"The list of things produced highlighted a number of areas that were already receiving attention.' [ManufIndProd].

- Able to prioritise the implementation of actions: "The workshop was a valuable way to prioritise the many competing objectives for the trust.", [Hospital A]; "I would have liked to get the group to prioritise the actions.” [Property]. 
- Agreed by the group members, rather than imposed or forced through: " Considering a range of departments were represented, it was interesting that the outcome was 'right' for all. Prior to the workshop I would not have thought this would be so.” [Housing]; " "The workshop enabled the group to agree on an action plan.', [R\&D].

- Informed by representatives of the right disciplines: "'Some key disciplines were missing ... it was apparent during the workshop that different disciplines had different needs and perceptions." [Property]; “The right mix of people from within the organization without peer pressure created a worthwhile day.”' [Ambulance].

- Built and shared by the group: "Whilst most actions could be identified independently of this session, the session gave a framework that made it easy for people to talk about the actions." [ManufIndProd]; "Efficient vehicle for the cohesive getting of different views in order to develop a strategy.'” [Police].

- The environment/process in and through which the action plan is built should:

- Encourage openness: "Being anonymous on the computer really allowed delegates to express their feelings.”' [Police]; “The degree of anonymity afforded by the (computer) approach can encourage greater openness, and ease of putting forward issues."' [ConsumProt].

- Be inclusive of all the group: " The outcome developed using this input of all of the team in an interesting and effective way.' [ManufIndProd]; "'(The workshop) enabled a diverse group to participate in a very open, dynamic way, where everyone could participate and benefit.' [Consult $\mathrm{B}]$.

- Support creative thinking: “As I mentioned during the day I had several 'light bulb moments' where a comment sparked ideas which I can certainly implement.” [B2B]; “Generally no reluctance to put forward off the wall suggestions." [High-TechManuf].

Developed through a logical, transparent process: "The majority of the benefits of the session are seeing how ideas developed over the course of the day. Just seeing the final output may not provide sufficient insight." [Hospital A]; "Provided a methodical approach to rationalising a mass of ideas into a workable number of action points." [B2B].

In terms of the influence of the strategies on the organizations participants felt that it was important that there should be:

- High-level commitment (possibly through a knowledge champion) to reinforce the importance of $\mathrm{KM}$ at the top of the organization: " $\mathrm{A}$ significant buy-in is required from the top of the organization down." [Hospital B]; ' 'Lack of interest/commitment at highest level. Need a champion at board level—no obvious willing candidate forthcoming." [Restaurants].

- Alignment of the strategy with core business needs and the organization's objectives: "We need to keep focus on who the main stakeholders are within 'service delivery' first i.e. the constable on patrol. There is a danger that a strategy of this type will focus on what support staff need and what they feel officer's need/want to know rather than what the officers think or falls in line with the way they work.,' [Police]; “'The workshop focused on the key priorities for (B2B) and was effective when linked with (B2B's) mission and objectives.' [B2B].

- Awareness that changes in the basic assumptions of organizational-life will disrupt implementation irrespective of group/individual dedication: “(Implementation will be) effected by large internal changes and key driving forces leaving the company." [Restaurants]; "Much hinges on [our] future, which at present is undecided. If we are to go forward in to the market place this was very useful and the measures could be adopted as an improvement programme."' [Property].

- Effort exerted to overcome cultural and political barriers to implementation: “(R\&D’s) culture may stifle KM implementation in the future-I hope not and will try to facilitate its implementation.", [R\&D]; “"The biggest challenge we face now (is) ... changing the business culture/mentality so that such a system can work effectively.' [Property].

- Sustained momentum through to completion: "We still have to maintain the energy and support each other in these issues. More 'storming' to go yet!' [ConsumProt]; "We must embark on these programmes, 'launch' arrangements, stop and check, and work with speed.' [Police].

- Recognition that execution needs to take place within imposed resource constraints: " As usual time management will be important to implement KM correctly." [ManufIndProd]; " A lot of points were made therefore only a few can be actioned." [Police]. 


\section{Evidence that dedication had been built}

The issues reflect some of the initial considerations participants had during and immediately following the development of their action plan.

\subsection{Indicators of commitment}

As intended, participants were interested in KM. Following the workshop, they agreed that "I think that knowledge management is an important issue in our organization', with a mean score of 1.42 .

The quantitative feedback (from Table 3) suggests that: participants were interested in $\mathrm{KM}$; the process was useful in generating an outcome; they were hopeful that outcomes would have effect, but were less confident that they actually would. The last point suggests that the participants were aware that the organization might not be receptive to the changes. On their questionnaire they often explained that this response was due to doubts over a receptive organizational culture and/or the support of the top management team.

In addition to the quantitative indicators, qualitative indicators from individual participants included: "it's the time to go further-so lets do it now." [Retail] and "I have the responsibility to make sure the outcomes influence (us) in the future." [Property].

6.2. Progress that organizations have made on implementing actions

Commitment is good but action is what matters. There seems little to be gained from being dedicated to a plan that is not executed. We now report on how 10 of the organizations made progress towards performing the actions, see Table 4:

- ConsumProt: A considerable amount of work by a top-level team in this organization has led to the ongoing implementation of nearly all the actions. Progress is reported in Shaw et al. [52].

- HighTechManuf: The execution of many of the actions was rapid, supported by an MBA student reporting to the workshop client [4].

- Hospital A: Subsequent to the workshop, a pilot KM system was developed and rolled-out.
Table 4

Progress on implementing knowledge management strategy

\begin{tabular}{|c|c|}
\hline Organization & Brief description of progress \\
\hline Ambulance & Progress unknown. \\
\hline B2B & Progress unknown. \\
\hline Consult A & $\begin{array}{l}\text { Have presented the actions to their } \\
\text { board for sanction and support. }\end{array}$ \\
\hline Consult B & Progress unknown. \\
\hline ConsumProt & $\begin{array}{l}\text { Successful execution of nearly all the } \\
\text { actions. }\end{array}$ \\
\hline DesignInst & Progress unknown. \\
\hline HighTechManuf & $\begin{array}{l}\text { Rapid implementation of most } \\
\text { actions. }\end{array}$ \\
\hline Hospital A & $\begin{array}{l}\text { Ongoing roll-out of system for } \\
\text { doctors. }\end{array}$ \\
\hline Hospital B & Ongoing. \\
\hline Housing & Progress unknown. \\
\hline ManufIndProd & $\begin{array}{l}\text { Managing director is overseeing delivery } \\
\text { of actions. }\end{array}$ \\
\hline Police & $\begin{array}{l}\text { Major strategy document informs project } \\
\text { work. }\end{array}$ \\
\hline Property & $\begin{array}{l}\text { Head of Knowledge Management is } \\
\text { overseeing the delivery of actions. }\end{array}$ \\
\hline Restaurants & $\begin{array}{l}\text { Key staff leaving the organization raised } \\
\text { a barrier to execution. }\end{array}$ \\
\hline Retail & Ongoing. \\
\hline $\mathrm{R} \& \mathrm{D}$ & Progress unknown. \\
\hline
\end{tabular}

- Hospital B: Work by a PhD student is contributing to the ongoing implementation and evaluation of initiatives, with an emphasis on risk management.

- Police: A change (twice) in top personnel hindered progress. Despite this, a major strategy document was written based on the actions developed during the workshop. Ongoing smaller projects feed into the initiative.

- Restaurants: A few days after the workshop a major re-organization resulted in a key driving force leaving the company. No action was taken on $\mathrm{KM}$ as competing priorities dominated resources. The organization has recently appointed a senior staff member who is supportive and has interest in the action plan.

- Retail: Following the workshop, a key manager said that his copy of the report detailing the agreed actions was “'heavily tea-stained," suggesting that it had been well used. Execution of actions was described as ongoing but it was competing for resources with other tasks.

\section{Discussion and implications}

7.1. The factors which action plans should have

The factors that participants felt were needed to 
warrant their commitment have been presented. This showed that the action plan should be achievable, focussed on relevant issues, appropriate for the breadth of the situation, prioritised, and informed by the right disciplines. We reviewed the nature of the environment/process in and through which the actions were developed and performed. A logical and transparent process should be used to encourage inclusivity, openness, and creative thinking. Also, sustained momentum on implementation (within resource constraints) should have high-level support and attention to lowering cultural/political barriers. Disruption or mis-alignment of strategy with the organization's objectives can jeopardise execution.

Probst et al. [45] identify, evaluating performance with appropriate measures, which was overlooked by participants in their questionnaire but discussed at length in all workshops.

\subsection{PSMs for building initial commitment}

Journey Making helped to facilitate a group through a messy problem: building an action plan. However, some participants lacked confidence that their plans would actually have any effect in the organization. They felt that the culture might stifle roll-out, and/or their perception that KM was not strongly supported by top managers. Despite these reservations the overwhelming feeling was of support for executing the actions.

The process of social negotiation is critical to the development of shared plans. Surprisingly, none of the participants refers to this on their questionnaires. Facilitators aim for the direction of the psychological/cognitive shift to be towards a shared outcome and for the driver for these psychological shifts to be persuasive argumentation where participants modify their views to the extent that they have been offered substantive reasons for so doing.

Using technology, participants can contribute their own views without being influenced by shared knowledge. As one participant noted, “It definitely allows participants to formulate their own [ideas] without any outside influence." [Police]. The ideas can then be displayed publicly, and time given for participants to identify unshared information and integrate that into their opinion formulation. Ensuing discussion will focus on all the (shared and unshared) information displayed on the public screen. Using the public screen as a negotiative device (and group memory) enables participants to negotiate more effectively as unshared information can be queried and illustrated with reference to a shared model, and not forgotten/overlooked.

\subsection{Communities of implementation}

In these workshops, we argued and participants declared that the plans have the participants' desire for implementation. Competing priorities may divert attention and resources as was the case in Restaurants when the significant internal changes redirected attentions away from KM. Strong leadership, prioritisation, alignment with a changing environment, emotional and psychological attachment to a group, progress reviews, and accountability all reinforce motivation and are essential for sustainability.

Mezias et al. [39] suggested that a workshop of "sseveral days", could move group members towards sustained commitment. We believe that, for sustainability, initial support should be reinforced outside of the workshop environment. One successful way we have used is by building a 'community of implementation’ (CoI) (with a focus on taking action).

ConsumProt built a CoI and this was a major factor in their implementing actions. For them, additional PSM workshops helped the CoI to problem structure new messy problems encountered during the execution. The knowledge champion had a central role in organizing the CoI, rather than being solely responsible for completion organization-wide.

\section{Conclusion}

Problem structuring workshops seemed effective in helping participants develop a feasible strategy and build their initial commitment to its implementation. An action plan from a workshop should be resilient enough to weather time and minor environmental changes, but it cannot be impervious to fundamental changes in the organization. For example, Restaurants and Police were both affected by senior personnel leaving the organization. This reinforced the importance of the knowledge champion-someone senior who was able to lead KM. In being senior, the 
champion would be aware of changing fundamental assumptions and able to give it an appropriate position on the agenda at a high-level.

For successful execution of actions, initial desire built during a problem-structuring workshop would need to be reinforced during the programme of change. A CoI can help here. It would meet to: monitor progress; identify changing environmental conditions which make execution problematic; structure solutions to these problems; and build a selfsustaining community through which commitment is reaffirmed and motivation bolstered.

A main limitation of this study is that the sample of organizations includes those organizations that have realised the need for KM but are aware of their deficiencies. It is unlikely that we would attract 'stars' or 'opponents' of KM, as they will either be confident in their practice, or unaware of (or uninterested in) the field. Also, our sample is limited by the lack of any IT companies and management consultancies. The study also lacks insight of what all of the organizations did with the action plan - whether commitment was maintained to completion in all cases.

Acknowledgement

The first phase of this research was sponsored by CIMA, the Chartered Institute of Management Accountants in the UK, and involved Dr. Paul Collier.

\section{References}

[1] F. Ackermann, C. Eden, SODA-journey making and mapping in practice, in: J. Rosenhead, J. Mingers (Eds.), Rational Analysis for a Problematic World Revisited, John Wiley and Sons, Chichester, 2001, pp. 43-60.

[2] M. Alavi, D.E. Leidner, Review: knowledge management and knowledge management Systems: conceptual foundations and research issues, MIS Quarterly (25) 2001, pp. 107-136.

[3] M.G. Assad, The $\mathrm{X}-\mathrm{Y}$ chart: a tool for systems designers, Information \& Management (2) 1979, pp. 175-179.

[4] R. Battams, Knowledge management strategy at <company name removed for confidentiality>, Aston Business School. MBA Thesis. Aston University, Birmingham, 2002.

[5] B. Berelson, Content Analysis in Commmunicative Research, Free Press, New York, 1952.

[6] R.P. Bostrom, R. Anson, V.K. Clawson, Group facilitation and group support systems, in: L.M. Jessup, J.S. Valacich (Eds.), Group Support Systems: New Perspectives, McMillan Publishing Company, New York, 1993, pp. 146-168.

[7] P. Checkland, Soft systems methodology, in: J. Rosenhead, J. Mingers (Eds.), Rational Analysis for a Problematic World
Revisited, John Wiley and Sons, Chichester, 2001 , pp. 6190.

[8] B. Choi, H. Lee, An empirical investigation of KM styles and their effect on corporate performance, Information \& Management (40) 2003, pp. 403-417.

[9] W.M. Cohen, D. Levinthal, Absorptive capacity: a new perspective on learning and innovation, Administrative Science Quarterly (35) 1990, pp. 128-152.

[10] J. Conklin, Wicked problems and social complexity, Working Paper of the CogNexus Institute, 2003 (Available at: http:// www.gdss.com/index.html).

[11] W.H. Cooper, R.B. Gallupe, S. Pollard, J. Cadsby, Some liberating effects of anonymous electronic brainstorming, Small Group Research (29) 1998, pp. 147-178.

[12] F.D. Davis, Perceived usefulness, perceived ease of use, and user acceptance of information technology, MIS Quarterly (13) 1989, pp. 319-339.

[13] A.R. Dennis, J.S. Valacich, T.A. Carte, M.J. Garfield, B.J. Haley, Research report: the effectiveness of multiple dialogues in electronic brainstorming, Information Systems Research (8) 1997, pp. 203-211.

[14] K.C. Desouza, Strategic contributions of game rooms to knowledge management: some preliminary insights, Information \& Management (41) 2003, pp. 63-74.

[15] M. Diehl, W. Stroebe, Productivity loss in idea generation groups: Tracking down the blocking effect, Journal of Personality and Social Psychology (61) 1991, pp. 392- 403.

[16] P.F. Drucker, Concept of the Corporation, revised ed., John Day Company, New York, 1972.

[17] C. Eden, F. Ackermann, Making Strategy: The Journey of Strategic Management, Sage, London, 1998.

[18] C. Eden, F. Ackermann, Group decision and negotiation in strategy making, Group Decision and Negotiation (10) 2001, pp. 119-140.

[19] J.S. Edwards, P.M. Collier, D. Shaw, Making a journey in knowledge management, Journal of Information and Knowledge Management (2) 2003, pp. 135-152.

[20] H.G. Enns, S.L. Huff, B.R. Golden, How CIOs obtain peer commitment to strategic IS proposals: barriers and facilitators, Journal of Strategic Information Systems (10) 2001, pp. 3-14.

[21] M. Fishbein, I. Ajzen, Belief, attitude and behavior: an introduction to theory and research, Addison-Wesley, Reading, MA, 1975.

[22] S.W. Floyd, B. Woodridge, Managing strategic consensus: the foundation of effective implementation, Academy of Management Executive (6) 1992, pp. 27-39.

[23] J. Friend, The strategic choice approach, in: J. Rosenhead, J. Mingers (Eds.), Rational Analysis for a Problematic World Revisited, John Wiley and Sons, Chichester, 2001, pp. 115150.

[24] B. Garvey, B. Williamson, Beyond Knowledge Management: Dialogue, Creativity and the Corporate Curriculum, PrenticeHall, Essex, 2002.

[25] P.H. Grinyer, A cognitive approach to group strategic decision taking: a discussion of evolved practice in the light of received research results, Journal of the Operational Research Society (51) 2000, pp. 21-35.

[26] V. Grover, T.H. Davenport, General perspectives on knowledge management: fostering a research agenda, Journal 
of Management Information Systems (18) 2001, pp. 5-21.

[27] M.T. Hansen, Knowledge networks: explaining effective knowledge sharing in multiunit companies, Organization Science (13) 2002, pp. 232-248.

[28] C.W. Holsapple, K.D. Joshi, Knowledge manipulation activities: results of a Delphi study, Information \& Management 39(6), 2002, pp. 477-490.

[29] G.P. Huber, Transfer of knowledge in knowledge management systems: unexplored issues and suggested studies, European Journal of Information Systems (10) 2001, pp. 72-79.

[30] A. Inkpen, Creating knowledge through collaboration, California Management Review (39) 1996, pp. 123-140.

[31] C.M. Jackson, S. Chow, R.A. Leitch, Toward an understanding of the behavioral intention to use an information system, Decision Sciences (28) 1997, pp. 357389.

[32] B.A. Jain, J.S. Solomon, The effect of task complexity and conflict handling styles on computer-supported negotiations, Information \& Management 37(4), 2000, pp. 161- 168.

[33] M.T. Jelassi, R.A. Beauclair, An integrated framework for group decision support systems design, Information \& Management (13) 1987, pp. 143-153.

[34] M.A. Korsgaard, D.M. Schweiger, H.J. Sapienza, Building commitment, attachment and trust in strategic decision making teams: the role of procedural justice, Academy of Management Journal (38) 1995, pp. 60-84.

[35] P. Legris, J. Ingham, P. Collerette, Why do people use information technology? A critical review of the technology acceptance model Information \& Management (40) 2003, pp. 191-204.

[36] Y. Malhotra, D.F. Galletta, Role of commitment and motivation in knowledge management systems implementation: theory, conceptualization, and measurement of antecedents of success, in: Proceedings of the 36th Hawaii International Conference on Systems Sciences, Hawaii, 2003.

[37] J. McKenzie, A. Truc, C. van Winkelen, Winning commitment for knowledge management initiatives, Journal of Change Management (2) 2001, pp. 115-127.

[38] J.P. Meyer, L. Herscovitch, Commitment in the workplace: toward a general model, Human Resource Management Review (11) 2001, pp. 299-326.

[39] J.M. Mezias, P. Grinyer, W.D. Guth, Changing collective cognition: a process model for strategic change, Long Range Planning (34) 2001, pp. 71-95.

[40] M. Newman, R. Sabherwal, Determinants of commitment to information systems development: a longitudinal investigation, MIS Quarterly 20(1), 1996, pp. 23-54.

[41] M. Parent, R.B. Gallupe, W.D. Salisbury, J.M. Handelma, Knowledge creation in focus groups: can group technologies help? Information \& Management (38) 2000, pp. 47-58.

[42] J. Pfeffer, The Human Equation: Building Profits by Putting People First, Harvard Business School Press, Boston,
1998 .

[43] L. Phillips, M. Phillips, Facilitated work groups: theory and practice, Journal of the Operational Research Society (44) 1993, pp. 533-549.

[44] M. Pidd, Tools For Thinking: Modelling in Management Science, John Wiley and Sons, Chichester, 1996.

[45] G. Probst, S. Raub, K. Romhardt, Managing Knowledge: Building Blocks for Success, John Wiley and Sons, Chichester, 2000.

[46] H.W.J. Rittel, M.M. Webber, Dilemmas in a general theory of planning, Policy Sciences (4) 1973, pp. 155-169.

[47] J. Rosenhead, J. Mingers, Rational Analysis for a Problematic World Revisited, John Wiley and Sons, Chichester, 2001.

[48] J. Roth, A. Styhre, Knowledge facilitation at AstraZeneca, European Academy of Management Conference, Stockholm, Sweden, May 9-11, 2002.

[49] D. Shaw, Evaluating electronic workshops through analysing the 'brainstormed' ideas, Journal of the Operational Research Society (54) 2003, pp. 692-705.

[50] D. Shaw, F. Ackermann, C. Eden, Sharing knowledge in group problem structuring, Journal of the Operational Research Society (54) 2003, pp. 936-948.

[51] D. Shaw, M. Westcombe, J. Hodgkin, G. Montibeller, Problem structuring methods for large groups interventions, Journal of the Operational Research Society (55) 2004, pp. 453-463.

[52] D. Shaw, J.S. Edwards, B. Baker, P.M. Collier, Achieving closure through knowledge management strategy, Electronic Journal of Knowledge Management (1) 2003, pp. 197- 205.

[53] H.A. Simon, From substantive to procedural rationality, in: S.J. Latsis (Ed.), Method and Appraisals in Economics, Cambridge University Press, Cambridge, 1976, pp. 424-443.

[54] R.H. Sprague, A framework for the development of decision support systems, MIS Quarterly (4) 1980, pp. 1-26.

[55] R.H. Sprague, E.D. Carlson, Building Effective Decision Support Systems, Prentice-Hall, Englewood Cliffs, 1982.

[56] M. Turoff, S.R. Hiltz, Computer support for group versus individual decisions, IEEE Transactions Communications, COM-30 (1) 1982, pp. 82-90.

[57] D. Ulrich, Intellectual capital equals competence $\mathrm{x}$ commitment, Sloan Management Review (39) 1998, pp. 1526.

[58] K. van der Heijden, C. Eden, The theory and praxis of reflective learning in strategy making, in: C. Eden, J.-C. Spender (Eds.), Managerial and Organizational Cognition, Sage, London, 1998.

[59] V. Venkatesh, Creation of favorable user perceptions: exploring the role of intrinsic motivation, MIS Quarterly (23) 1999, pp. 239-260.

[60] L.R. Weingart, R.J. Bennett, J.M. Brett, The impact of consideration of issues and motivational orientation in group negotiation process and outcome, Journal of Applied Psychology (78) 1993, pp. 504-517. 


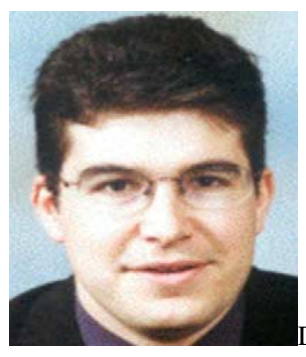

Duncan Shaw is a Senior Lecturer in Aston Business School, Birmingham, U.K. He has a BA and a PhD from Strathclyde University, Glasgow. His research interests include evaluating group decision support technologies, problem structuring methods and facilitation. In research and consulting capacities he has recently supported groups on a variety of topics including knowledge management, strategic planning and implementing strategy.

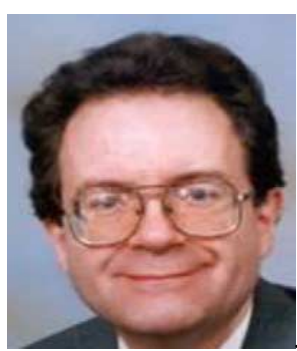

John S. Edwards is Professor of Operational Research and Systems, and Head of Academic Programmes at Aston Business School, Birmingham, U.K. He has an MA in mathematics and a $\mathrm{PhD}$ degree from the University of Cambridge. His doctorate was in human resource planning models. His principal research interests now are in knowledge management, especially methods for the development of knowledge-based systems and decision support systems. He has published more than 40 research articles on these topics, and two books, Building Knowledge-based Systems and Decision Making with Computers. He is editor of the journal Knowledge Management Research \& Practice. 